\title{
Designing Sustainable Banking Services: A Study of Indian Banks
}

\author{
*Sarath Chandran M.C. \& **Dr. B. Sathiyabama \\ *Research Scholar \& **Research Guide and Assistant Professor \\ $P G \&$ Research Department of Commerce \\ Marudupandiyar College of Arts and Science, Vallom, Thanjavur \\ Affiliated to Bharathidasan University, Tiruchirappalli \\ Mail id-chandranmcsarath@gmail.com
}

\begin{abstract}
Since the genesis of $21^{\text {st }}$ century, sustainable development has been one of the key growth concerns for many developing countries. Designing services have taken a new shape with implications of sustainability being the heart of many significant developments in the financial industry in India. Considering the requirements of the regulatory framework and policy makers, banks are encouraged towards adopting a more pro-active and sensible approach towards designing their product services. These are in view of better serving their customers and cater for future developments. The purpose of their paper is to enquiry into the basis of sustainable service design aspect of banks in the Indian context despite its undisputed value for financial organisations attempting to comply with sustainability framework and policy makers to develop a sustainable development culture. The research design is exploratory in nature, which comprises extensive literature review coupled with indepth qualitative data collection from selected industry practitioners. The literature reviews clearly indicates the significance, value and power of sustainable service design. Based on results of the literature review and collected data, managerial extrapolations have been devised. To our knowledge, there has been no evident effort to investigate this research in the Indian Service banking industry regardless of the richness and value it holds.
\end{abstract}

Keywords: Sustainable Banking, Sustainable Development, Banking Services, Sustainable Services.

\section{Introduction}

In contrast to the existing development narrative, which over-exploits the natural environment for economic gain, sustainable development has arisen as a new paradigm of development. Allowing markets to operate within an adequate framework of cost-effective rules and economic instruments is the greatest way to accomplish long-term development. Financial institutions, such as the banking industry, are one of the key economic factors impacting overall industrial activity and economic growth. The banking industry has an impact on economic growth and development, both in terms of quality and quantity, and so alters the character of economic growth. One of the most significant economic activities for economic growth is the banking sector, which is one of the key sources of financing 
investment in commercial enterprises. As a result, the banking sector has a critical role to play in encouraging ecologically sustainable and socially responsible investment.

Sustainable development necessitates a holistic approach that balances environmental concerns with economic progress. According to the United Nations Brundland Commission in 1987, sustainability is defined as "filling current demands without jeopardising future generations' ability to satisfy their own needs."

\section{Rationale of the Study}

The goal of this research is to learn more about how Indian banks implement sustainable banking and what goes into their sustainable service designs. Though sustainable development has sparked a lot of interest in India over the last few years as a research topic, the field of sustainable banking is yet to be explored. Local banks take pride in being more committed to sustainable development and actively engaged in the development of more environmentally friendly products and services. There is a need to analyse the extent to which our local banks' sustainable banking philosophy includes a sustainable design approach.

\section{Purpose of the Study}

The major purpose of this study is to highlight the most essential aspects that drive local banks' sustainable banking practises.

\section{Objectives of the Study}

The specific objectives of the research as are follows:

i. To determine which sustainable banking practises have been applied in India.

ii. To evaluate the local bank's sustainable service design approach.

iii. To assess the strategies used by local banks for long-term growth and management.

\section{Literature Review}

\section{Sustainable Development}

"The banking sector has been slow to address sustainable development," according to Lynch (1994) and Jeucken (2001). Although banking operations are relatively clean in comparison to other sectors and their products and services do not cause pollution, this method is useful when just the direct impact of banking operations and energy and material usage is evaluated. It is easier to reveal the banking sectors direct impact to stakeholders because acknowledging such consequences is not a significant burden on society (Bouton et al., 2001; Cowton and Thompson, 2000).

According to Jeucken (2001), banks act as an intermediary by transforming money based on "location (for example, a bank can allocate money from a lender to a borrower in a different location), term plans (brokerage up to maturity - creditors typically only have short-term liquidity surpluses, while debtors often have long-term capital requirements), and risk (banks 
are generally in a better position to assess individuals' risks)," which influences the direction and development of the economy. As a result, banks can tailor their financial policies to generate chances for sustainable development, delivering green investment advice to their clients as well as information on market sectors, market development, and laws.

\section{Sustainable Finance}

Hart and Ahuja (1996) conducted a study that found a link between financial and environmental performance. Most banks were first examining their financial performance, but now is the time to conduct a social and environmental performance study. Green Banking is more than simply a CSR activity for a company; it's also about making the company habitable without causing harm.

"Sustainable finance awards" were introduced by the "International Finance Corporation (IFC) and the Financial Times, a member of the World Bank Group," for those organisations that include environmental policies and are concerned about corporate governance in their commercial activities. The relationship between financial and non-financial companies that are finding innovative and financially viable solutions to sustainability concerns was emphasised in the awards. The five categories of Financial Times awards for sustainable finances (FTIFC Awards, 2014) are:

- Technology in Sustainable Finance

- Achievement in Inclusive Business

- Sustainable Investment of the Year

- Sustainable Bank of the Year

- Sustainable Investor of the Year

\section{Sustainable Banking}

"However, dueto their function as an economy's middleman, the role of banks in contributing to sustainable development has huge potential." Banks change money in terms of duration, magnitude, location space, and risk, and have a significant impact on a country's economic development. Because banks may impact the rate and direction of economic growth, they have a quantitative as well as qualitative influence." Jeucken (2004) is a writer who has written a number of books on the subject.

The banking industry holds responsible for its impacts on the economy and society, as well as the impacts of their customers - "those they fund" - as a "integral driver" and enabler of economic development and growth (EY, 2014). Stakeholder confidence in the banking system had already been shaken by the global crisis, and recent regulatory and compliance challenges, such as LIBOR and anti-money laundering, have only exacerbated this.

(Case, 2012) asserts that banks should take calculated risks and avoid overexposure in ecologically and socially sensitive industries because such exposure can result in severe financial, legal, and reputational consequences. 
Organizations with "sustainability at the centre of their plans," according to (Eccles, 2012), consistently outperform in terms of value, portfolios, and return on equity (ROE).

Sustainable banking, according to (Straw, 2014), offers a lot of profit and return potential, but it cannot be a haphazard venture; rather, it must emerge from a managerial mindset to establish a sustainable development culture.

\section{Cultural sustainability}

Sustainable banking, according to (Gelder, 2007 \& Straw, 2014), is impossible without a culture shift within the organisation. They also claimed that the concepts of sustainable banking must be deeply ingrained in business culture.

(EY, 2014) advocates the cultural component in sustainable business, operations, products, and service designs, as well as ensuring that corporate behaviour is also sustainable, in order to produce a well-synchronized banking institution that isn't only looking for a fractional approach to sustainability.

\section{Technological Sustainability}

According to (Walker, 2008), sustainable banking is a topic that necessitates that the sustainability orientation pervades banks at all levels, particularly at the business management and operational levels, where leveraging on the intelligent use of technology can prove to be particularly useful in rendering banking processes more effective and efficient, thereby improving the use of material and human resources, as well as customer experience and productivity.

(Case, 2013) claims that reducing internal procedures will help banks become more sustainable in terms of having a more productive operational system with less resources while also improving customer experience.

\section{Sustainability on Regulators Cell}

\section{Sustainability Group Indices of Dow Jones}

The Dow Jones Sustainability Group Indexes announced the launch of the first international indexes for top firms to track their sustainability performance in September 1999.

\section{Banking Declaration on Sustainable Development and Environment}

The "United Nations Environmental Program (UNEP) and five associates of the Advisory Committee (Royal Bank of Canada, Deutsche Bank, NatWest Bank, Westpac Banking Corporation, and Hong Kong \& Shanghai Banking Corporation)" were all involved in the development of the "Statement by Banks on Environment and Sustainable Development" in 1992. The statement was signed by all five of the committee's associated members. Only 23 of the world's top commercial banks joined the UNEP accord by the end of 1992. 


\section{Finance Report of EPI}

The EPI-Finance 2000 report was started by a group of 11 commercial banks, and it demonstrates the difficulties that banks confront in reporting and measuring their environmental performance from their activities. The report was written to help "create a complete picture of a company's sustainability performance, which allows for better management decision-making and stakeholder interaction, as well as meaningful benchmarking," according to the authors.

Environmental indicators, according to Searcy et al. (2007), assist firms in monitoring their performance against goals and reporting their progress to shareholders.

Environmental indicators, according to (Isaksson and Garvare, 2003), can provide internal direction in order to measure the success of ecological management and, on the surface, to aid as a reliable environment related statement to shareholders.

\section{Overview of Indian Banking Industry}

India has been on a higher growth path for the past 15 years, with the industrial sector playing the most essential part in the country's development. However, controlling the environmental impact of their business, i.e., minimising pollution and emission of their clients, is a difficulty for Indian industry. Though the government has attempted to address the problem by enacting environmental legislation and encouraging industry to adopt environmentally friendly technologies and practises, these efforts have been ineffective due to a lack of enforcement, public awareness, and the inability to gain a competitive advantage by producing environmentally friendly goods.

In terms of greenhouse gas emissions, India is the world's sixth largest and second fastest expanding country. Three of the world's ten most polluted cities are Delhi, Mumbai, and Chennai. (a) Primary metallurgical industries, such as zinc, copper, and steel, are the most polluting industry in India. b) paper and pulp c) pesticides/insecticides d) refineries e) fertilisers f) tanneries g) sugar h) textiles I chemicals/pharmaceuticals financial institutions' banking operations and investments should focus on improving the overall environment, the quality and conversation of life, the efficiency with which resources and energy are used, and the quality of services and goods provided by these polluting businesses. In this context, the banking sector, which is one of the key sources of financing for the industries, plays a critical role.

\section{Indian Banking Industry - Phases of Transformation}

\section{Phase I - Evolutionary Phase Prior to 1950}

In terms of greenhouse gas emissions, India is the world's sixth largest and second fastest expanding country. Three of the world's ten most polluted cities are Delhi, Mumbai, and Chennai and that too in India is a bad impression to home country. (a) Primary metallurgical industries, such as zinc, copper, and steel, are the most polluting industry in India. b) paper 
and pulp c) pesticides/insecticides d) refineries e) fertilisers f) tanneries g) sugar h) textiles I chemicals/pharmaceuticals financial institutions' banking operations and investments should focus on improving the overall environment, the quality and conversation of life, the efficiency with which resources and energy are used, and the quality of services and goods provided by these polluting businesses. In this context, the banking sector, which is one of the key sources of financing for the industries, plays a critical role.

\section{Phase II - Foundation - 1950 - 1969}

For starters, the banks have branches outside of India, which might lead to political issues and large-scale implications. Second, nationalisation was thought to deprive banks of their useful commercial operations and functions. The Reserve Bank of India appointed the "Committee of Directors of the "All India Rural Credit Survey" in 1951, and the State Bank of India (SBI) was established as a result of their proposal. During this time, the number of commercial banks shrank dramatically. As of December 1951, there were 566 banks in the United States, with 92 scheduled banks and 474 non-scheduled banks. By the end of 1968, the number had plummeted dramatically to 281 people. The substantial decline in the number of banks was due to a sharp drop in the number of non-scheduled banks, which fell to an alltime low of 210 .

\section{Phase III - Expansion - 1969 - 1984}

The goal of bank nationalisation, often known as the "first-banking revolution," was to make banking services available to the whole public. Through quick branch expansion, deposit mobilisation, and credit creation, commercial banks were critical to the mission's success. The aim for geographic development in the form of branch expansion has continued to pervade into rural areas. On April 15, 1980, the $2^{\text {nd }}$ round of nationalisation 6 more commercial banks enlarged the phase of public sector banks, requiring banks to adopt all government-sponsored programmes and shift their attitudes in favour of social banking, which was given high priority.As a result, throughout this period, the Indian banking system underwent a significant shift with far-reaching implications, as it gained a large mass base and emerged as a critical tool of socioeconomic change. As a result, with expansion came incompetence and a loss of control over a large number of offices. Furthermore, retail lending to more risky locations at low interest rates resulted in higher costs, lowered the quality of banks' assets, and harmed their profitability.

\section{Phase IV - Consolidation - 1984 - 1990}

This phase began in 1985, when a series of policy initiatives were implemented with the goal of concentrating the profits from bank branch development and loosening, albeit little, the system's tight control. Despite the fact that the number of schedule banks expanded from 264 in 1984 to 276 in 1990, bank branch expansion stalled. During this time, only about 7000 branches were constructed. For the first time, serious consideration was given to improving bank housekeeping, customer service, credit management, employee productivity, and profitability, and concrete initiatives were done during this time to streamline bank deposit and lending rates. Measures were taken to alleviate structural constraints that were impeding the development of the money market. 


\section{Phase V - Reformation - 1990 - 2000}

Since the nationalisation of banks in 1969, India's banking system has remained controlled and inflexible. Until 1990, there was no need for an independent monitoring authority. Despite commendable progress in the post-Nationalisation period, certain banking sector issues have emerged, resulting in a decline in productivity and efficiency, as well as a loss of profitability. The forces working on both the income and spending sides have contributed to the fall in profitability.

\section{Methodology}

The study's major goal is to provide insight into the image of sustainability that exists in the Indian banking sector. And the second phase of the research would incorporate data collection from published sources about banks in India. The audited and provisional financial reports of the concerned banks for the financial years 2017 - 2020 were used as secondary public sources for this investigation. We limited the sample to two large Indian banks, one private sector and one public sector, ICICI and SBI, in order to explore the entire range of sustainable banking in India. In terms of market capitalization, these two banks account for over half of the Indian banking sector.

The pragmatic analysis has been structured as follows:

a. An examination of how sustainability is translated into organisational practises, with an emphasis on the environmental, social, and economic dimensions.

b. The Global Alliance for Banking on Values Report's measurement of bank sustainability in terms of financial performance (Mar 2020).

\section{Analysis and Discussion}

\section{a. Based on Organisational Practices}

\section{i. Environmental Aspect}

\section{ICICI Bank [P] Ltd.}

- As the largest private sector bank, ICICI has recognised its environmental responsibilities. The bank has placed a premium on the fact that its facilities, operations, and activities should all be founded on the concept of Sustainable Banking and contributes to environmental conservation. The Bank has taken a number of steps in this approach.Most significantly; the bank has launched the facilities of instabanking and vehicle finance and home finance. ICICI has understood that these initiatives and activities can ensure its sustainability for the longer period of time.

- Insta-banking is a green product or service that allows users to access their bank accounts and services from any location and at any time. Mobile banking, net banking, and IVR banking are all included. 
- ICICI Bank has come up with schemes where they waive off 50 percent processing fee if someone is buying the product which saves and uses an alternative mode of energy. Car models like Reva electric cars, Mahindra Logan CNG versions and so on fall in this category.

- Banks have alsowaived processing fees for those customers who buy leadership in energy and environmental design certified buildings. This states that ICICI is committed towards Sustainable Banking policy and makes sure that common people also tread the same path.

- Other initiatives undertaken are;

a. Pricing of ATM balance enquiries and mini statements and receipts to reduce unnecessary printing and litters.

b. Launch of $\mathrm{E}$ - statements to the customers through $\mathrm{e}$ - mail

c. Green loan for corporates in collaboration with foreign banks

d. Green loan for individuals wishing to install solar systems for the productivity of electricity for their own.

e. Rainwater harvesting scheme (Feb, 2018)

\section{State Bank of India}

- Since SBI is the largest public sector bank in India the responsibility of SBI is mammoth in taking the initiatives related to Sustainable Banking. SBI is active into various banking operations and operates globally. The bank has focused on following the Sustainable Banking practices and supporting other banks as well to follow similar steps. The major initiative taken by the bank was that they eliminated the queue banking in approximately 7000 plus branches pan India. In additional, the bank has come up with green channel counters as well as the construction of wind farms in India.

- In India, the state bank of India is the first company that introduced Green Banking policy and to showcase social responsibility, the bank fulfilled its duties towards society and nature. The SBI also supports a clean environment policy, with additional focus on the preservation of the environment by utilising high energy efficient deviceswhich comply with applicable environment laws, regulations and standards. SBI has reduced paper consumption, introduced emailing statement of accounts to and continuously educating customers to use the internet banking facility to access their account statements.

\section{ii. Social Aspect}

\section{ICICI Bank}

- The bank has come up with go green movement involving most number of people. The company communicated all the elements to the customers that can help in aiding go green movement.

- Other initiatives are made up of recycling ofthe paper internally, limited printing and extensive usage of e-mails and voicememos instead of paper memos. 
- The bank introduced an environmental and social policy which has been in effect since $30^{\text {th }}$ May 2015, the main purpose of which is to set out the principles, policies, roles and responsibilities whereas the bank should take into consideration the social and environmental aspects of any specific project.

- The bank adopted Equator Principle on $15^{\text {th }}$ May 2013, which stands out as a governing principle of the environmental and social policy. Equator principle relates to a risk management framework which is undertaken by many banks globally mainly for determining, appraising and managing the environmental and social risk in projects.

- CSR activities is responsible for the efficient and effective design, implementation and management of initiatives contributing towards incorporating the group's engagement within the customers and society.

- The bank has encouraged flexible working arrangements with regard to absolute poverty eradication and community empowerment, welfare of children, education, health and leisure and sports to the design of dedicated programmes to focus on building human capital while fostering a continuous learning culture across the group.

- Go social is a campaign through which bank runs through social media and tries to connect to a wide range of people.

\section{State Bank of India}

- State Bank of India has contributed in various kinds of social cause and community services.

- The main priority areas of SBI focus on empowerment through education and social housing. Inspite of this with the alliance of group effort empowerment through education to warfare poverty, a unique scholarship scheme for bright and needy students was introduced through TheSBI Education Fund in the FY 2012.

- They also came up with special scheme for Technical Vocational Educational Training sector in first batch in the FY which ended in 2012.

- The bank has also practiced in adopting of the girl child, tree plantation, facilitating education and providing medical facilities as well.

- The bank has shown its attention to the environmental issues like global warming and climate change. Moreover, the attention has been transferred towards the paperless banking. It was the greatest initiative taken by State Bank of India.

- The bank has also taken a step related to installing its windmills for the generation of green power.

- SBI has actively engaged its service units and has identified some selected 50 NGO's across the country to finance their micro-projects in the FY 2016.

- They also supports the involvement of its employees within various causes across the country including initiatives for disabled persons, vulnerable children and senior citizens. 


\section{iii. Economic Aspects}

\section{ICICI}

- Other than internal banking operations, the bank has started to promote go green movement, so that maximum number of people becomes part of such movement.

- The company communicated all the elements to the customers that can help in supporting go green movement. The main accent is introduction of online fund transfer and online bill payment facilities.

- Most drastic change is related to using the webinars for meetings just to avoid the travel distance. Thus, the efforts of these banks are not only limited to their banking operations, but also with changing regular and daily habits of people.

- ICICI celebrates world environment day and try to make people aware of the environment issues. On this day the bank is involved in plantation activities, and employees of the company are encouraged to get their vehicles PUC checked.

- The bank also internally created "Initiative 150 Programmes" aimed at promoting environment -friendly practices.

- The bank has become the main provider of Green Loans, offers credit facilities to help firms to save energy and reduce carbon emissions into the environment. As on June 2016, more than 100 companies and individuals have benefited from such facilities.

- In contributing to the development of SME's (Small and Medium Enterprises, the bank has been ranked in the first $10^{\text {th }}$ among the 19 other nationalised and nonnationalised banks operating in the country in respect of credit facilities approved under the Government backed support SME financing.

\section{State Bank of India}

- SBI has entered into tie-ups with several external consultants in order to execute better strategies for the economic-ecological solutions. The problems like carbon emissions and setting benchmark for the same is also a prime agenda for SBI.

- SBI has involved its stakeholders too in following Green Banking policy. The manufacturers and other companies got loans at lower rates if they follow green policies.

- The first Green Banking branch of SBI was inaugurated in the year 2012 in Kohima. To make this event successful and connecting more people with the initiatives, the bank distributed eco-friendly waste bins to local villagers.

- The bank donated water purifier to the neighbouring schools of its premises.

- SBI has received an award for the installation of best green ATM at several places pan India. The Bank encouraged its customers to use electronic documents instead of using papers for instance to view annual reports.

- SBI introduced eco-loan facility whereby credit facilities are provided to customers to install solar panels to generate electricity for self-use plus selling to the national grid.

- In recognition of the importance of SME to the domestic economy, SBI has reviewed the structure and processes of its Small Medium Enterprises line of business with the help of famous global consultancy firms. In order to achieve new heights, SBI plans 
to leverage on its branch network and its new operating model defined around regional hubs while promoting new and innovative solutions that suits well the changing needs of customers.

\section{iv. Financial Performance Aspect}

Based on the reports of the RBI (2015), a comparison of sustainable banks to Global Systematically Important Financial Institutions (GSIFI's) led to the following conclusions:

- Sustainable banks had significantly greater exposure to customers in both deposits and loans

- Sustainable banks fund a much larger portion of their total balance sheet with customer deposits

- Sustainable banks have much higher level of equity to total asset with slightly higher level capital ratios

- Sustainable banks had better return on assets with comparable return on equity

- Sustainable banks had significantly higher levels of growth in loans and deposits, leading to higher growth in assets and income

Based on financial ratios of ICICI and SBI, the following analysis is made:

- Total loans to total assets: ICICI has a higher proportion of its assets invested in loans compared to the SBI.

- Total deposits to BIS (Bank for International Settlement) ratio: SBI has higher level of ROA and ROE.

- ROA to ROE: SBI has higher levels of ROA and ROE as compared to the ICICI especially in most recent years.

- Loan growth to deposit growth: ICICI has higher level of growth in loans and deposits as compared to SBI in the FY $2017-2018$

- Asset growth: The growth of assets in both the banks fluctuated throughout the years.

The above analysis is based on the report submitted by cited banks to RBI. While the ICICI leads the way with regards to the Total loans to total assets, total deposits to total assets and loan growth to deposit growth ratios, the situation is reversed from the perspective of equity to assets and BIS ratio and Return on Assets to Return on Equity ratios. So here, a clear cut conclusion cannot be drawn from the above analysis.

\section{Conclusion and Recommendation}

The concept of sustainable banking in the Indian banking sector is still subject to a wider scope of study. Though, significant links have been identified in the previous studies between sustainable development and banking, the study found out that, though progress is being made by the two major banks to lay more emphasis on sustainability, there is a call for the development of standardised and clear metrics. Only if this is carried out successfully, it 
can show the impact of these banks on people and the environment and for investment decisions. Some progress has also been made in the Indian Banking Sector, even if the emphasis is more on CSR (Corporate social Responsibility). Nevertheless, sustainability goes beyond that. Another matter of concern was that no separate CSR report was available with the two major banks in their annual financial report.

The focus of sustainable banks on customer lending and deposit taking is directly relevant to policy makers and regulators. This not only maintains the critical functioning of the banking system but alsosupports the general economy globally. Sustainability can affect the decision making as it is an ever ending process and is in a loop. With the emerging challenges and new goals, banks need to review their frameworks, policies and strategies to reach the top of its commitments towards sustainability.

\section{References}

1. Aboelmaged M, Gebba TR. (2013) Mobile banking adoption: An examination of technology acceptance model and theory of planned behaviour. International Journal of Business Research Development, 2(1).

2. Achua J. (2008). Corporate Social Responsibility in Nigerian Banking System. Society and Business Review, 3 (1), 57-71.

3. Ahmad Bello Dogarawa (2006). An Examination of Ethical Dilemmas in the Nigerian Banking Sector. Munich Personal RePEc.

4. Ajzen I. (1991). The Theory of Planned Behavior. Organizational Behavior and Human decision processes. 50(2)

5. Baraghani S. (2008). Factors Influencing the Adoption of Internet Banking. Lulea University of Tecnology, Barketing and E-comerce.

6. Baskin, J. (2006). Corporate responsibility in emerging markets. Journal of Corporate Citizenship, 24, 29-47.

7. Beatty, R.C., Shim, J.P., \& Jones, M.C. (2001). Factors influencing corporate web site adoption: A time based assessment. Information and Management, 38(6), 337354.

8. Benedikter, R. (2011). Answer to the economic crisis: Social banking and social finance. Spice Digest, New York: Springer.

9. Bouton, D.L. and R.G. Lynch. (2001). The Measurement of Inequality and Poverty: A Policymaker's Guide to the Literature. World Development, 22(4), 567-578.

10. Case (2012) “Impact of Economic Reforms on Indian Banking”, Indian Economic panorama: quarterly Journal of Agriculture, Industry, and commerce.

11. Cheung, S.F., Chan, K.S., and Wong, S.Y. (1999). Re-examing the Theory of Planned Behavior in Understanding Wastepaper Recycling. Environment and Behavior, 31(5), 587-612.

12. Cowton, C.J., Thompson, P. (2000). Do codes make a difference? The case of bank lending and the environment. Journal of Business Ethics, 24 (2), 165-178. 
13. Curran, J. (2013). Self-Service Technology Adoption: Comparing Three Technologies, Journal of Services Marketing, 19(2), 101 - 130.

14. Dr. K.M. Chinnadurai and K. Sudhalakshmi. (2014). The international Journal of Business and Management, 2(4)

15. Eccles (2012). The Concept of Environment Sustainability. Annual Review of Ecology and Systematics, 26, 1-24.

16. Ernst \& Whinney Arthur Young \& Co., Kollewe, Julia (4 May 2020). "Watchdog investigates EY audit of scandal-hit NMC Health". The Guardian. Retrieved 15 November 2020.

17. Fredricks, A.J., and Dossett, D.L. (1983). Attitude-Behaviour Relations: A Comparison of the Fishbein-Ajzen and the Bentler- Speckart Models. Journal of Personality and Social Psychology, 45, 501-512.

18. Gatignon, Hubert, and Thomas S. Robertson. (1989). Technology Diffusion: An Empirical Test of Competitive Effects. Journal of Marketing, 53(1), 35-49.

19. Gelder and Straw (2014). Internet/e-Business Technologies. Emerald Group Publishing Limited, Vol. 21 (No. 3), pp. 255-281.

20. Goodland, R. (1995). The Concept of Environment Sustainability. Annual Review of Ecology and Systematics, 26, 1-24

21. Hart, S. L. \& Ahuja, G. (1996). Does It Pay To Be Green? An Empirical Examination of The Relationship Between Emission Reduction And Firm Performance. Business Strategy and Environment, 30-37.

22. Hoijtink (2005). The Sustainability Attitude of Commercial Banks. University of Tilburg, 2005.

23. Isaksson \&Garvare (2003), Summated Rating Scale Construction: An Introduction, Quantitative Applications in the Social Sciences, Series No. 07-082, Sage, Newbury Park, $C A$.

24. Jeucken M. (2001). Sustainable Finance and Banking: Slow Starters are Gaining Pace. http://www.sustainability-in-finance.com/ifi.pdf

25. Jeucken M. (2001). Sustainable Finance and Banking: Slow Starters are Gaining Pace. http://www.sustainability-in-finance.com/ifi.pdf.

26. Jeucken M. (2004), Sustainability in Finance. Eburon Academic Publishers, 1st edition, Delft.

27. Kurup, Parameswaran Narayana (1963), "Some aspects of commercial banking in India since 1939" post graduate Diploma Thesis; Gujarat University. Department of Economics Ahmedabad

28. Lynch W. (1994). Segmenting the non-adopter category in the diffusion of Internet banking. International Journal of Bank Marketing, 23(5), 414-437.

29. Mattila, M., H. Karjaluoto, and T. Pento. (2003). Internet banking adoption among mature customers: early majority of laggards?. Journal of Services Marketing, 17(5), 514-528.

30. Nidumolu, R.; Prahalad, C.K.; Rangaswami, M.R. (2009). Why sustainability in now the key driver of innovation. Harvard Business Review, 87(9), 56-64.

31. Rai, A., \&Patnayakuni, R. (1996). A Structural Model for CASE Adoption Behaviour. Journal of Management Information Systems, 13 (2), 205-234. 
32. Ramus, Catharine A., Steger, Ulrich. (2000). The roles of supervisory support behaviors and environmental policy in employee 'ecoinitiatives' at leading-edge European companies. Academy of Management Journal 43(4), 605-626.

33. Searcy, et al. (2009). The Corporate Social Responsibility of Project Finance Lenders: An Investigation into the Lending Behavior of the Equator Principles Financial" Institutions. http://arno.unimaas.nl/show.cgi?fid $=16773$.

34. Straw (2014). Green Banking Practices in Indian Banks. International Journal of Management and Commerce Innovations, 2 (1), 232-235.

35. Walker, Margaret Craig-Lees, Robert Hecker, Heather Francis. (2008). Technology-enabled service delivery: An investigation of reasons affecting customer adoption and rejection. International Journal of Service Industry Management, 13 (1), 91-106.

\section{Websites and Reports}

1. ACCA. (2004). Towards transparency: Progress on global sustainability reporting. London.

2. https://development.asia/explainer/green-finance-explained (Asian Development Bank)

3. https://economictimes.indiatimes.com/small-biz/productline/power-generation/solarsubsidies-government-subsidies-and-other-incentives-for-installing-rooftop-solarsystem-in-india/articleshow/69338706.cms?from $=m d r$

4. https://www.ifc.org/wps/wcm/connect/news_ext_content/ifc_external_corporate_site/n ews +and+events/news/2013+ft+ifc+sustainable+finance+awards+winners+announ ced

5. https://www.un.org/en/academic-impact/sustainability

6. https://www.unenvironment.org/regions/asia-and-pacific/regionalinitiatives/supporting-resource-efficiency/green-financing

7. ICICI Bank (2013). Annual Report 2012-13: Vadodhara, ICICI bank

8. SBI (2013), 2012-13 Annual Report, Mumbai, SBI 